\title{
Determinants for Banking Governance in Indonesia
}

\author{
Sotarduga Napitupulu1 ${ }^{1}$, Ina Primiana ${ }^{2}$, Sulaeman R $^{2}$, Nidar ${ }^{2}$, and Nury Effendi \\ ${ }^{1}$ Student of Doctoral Program, Department of Management, Padjadjaran University Bandung- \\ Indonesia \\ ${ }^{2}$ Lecturer, Department of Economy and Business, Padjadjaran University Bandung-Indonesia
}

Corresponding Author:

Sotarduga Napitupulu

sotarnapit@gmail.com

Received: 10 February 2019

Accepted: 14 March 2019

Published: 28 March 2019

Publishing services provided by

Knowledge E

(ㄷ) Sotarduga Napitupulu

et al. This article is distributed

under the terms of the

Commons Attribution License,

which permits unrestricted use

and redistribution provided that

the original author and source

are credited.

Selection and Peer-review under the responsibility of the ICIEBP Conference Committee.

\section{Abstract}

Objective: This study intends to conduct an empirical investigation to find the factors that determine good corporate governance on banking industry in Indonesia. Methodology: The method used in this article is partial least square regression.

Results: The findings show that the leadership variables strengthen the quality of GCG practice. Fit and proper variable is proven to strengthen the influence of leadership variables on the quality of GCG practice.

Implication: In the context of banking industry sustainability, concerns are paid to the potential and competitive strategy of bank. The performance of commercial bank requires structuring the quality of Good Corporate Governance (GCG) practices to be able to face and sustain in business risk. The greatest challenges arise from identifying determinants for banking governance to be sustained in Indonesian banking industry.

Keywords: leadership, good corporate governance, fit and proper.

\section{JEL classification: G21 •G28 •G32 •L21 • O47}

\section{Introduction}

Governance of financial institutions is a serious issue when the financial industry of the United States and Europe is hit by a crisis several years ago. Djokic \& Duh (2016) argues that fraud cases, accounting scandals and business failures that occur throughout the world that usually lead to legal problems or bankruptcy make corporate governance a very important topic. Even Lenssen, et al. (2014) concluded that the 2008-2012 financial crisis showed a continuing global system failure and corporate responsibility due to weak / limited corporate governance in contributing to sustainable business in sustainable economy. However, even though there has been a lot of research relating to GCG practices, the study of GCG practices in the banking industry has never investigated the factors that determine the quality of GCG practices in banks, especially Indonesian 
banks. This research intends to study the determinants of GCG quality in banking practices, especially leadership and fit and proper test.

\section{Literature Review}

\subsection{Leadership}

Bass (1985) further states that there are 5 dimensions of transformational leadership, i) Vision, ii) Inspiring communication, iii) Supportive leadership, iv) Intellectual stimulation, and v) Personal recognition. The idea of Bass (1985) about transformational leadership is more than just giving a stimulus to get the desired performance through developing, intellectual stimulation and inspiring followers to achieve something beyond their personal interests into greater interests (interests, mission and shared vision). This behavior broadens the scope of leadership, more than just doing corrective or constructive activities. He placed transformational leadership as a construct consisting of three conceptual factors, namely charisma, intellectual stimulation, and individual consideration.

Leaders who are considered transformational are leaders who focus their efforts on long-term goals, place value and prioritize the development of vision. This type of leader inspires followers to pursue a vision and change or adjust the system to accommodate his vision rather than working within the existing system. They train their followers to take better responsibility for the development of themselves and others. Then, Van (2005), Nave (2006), Plowman et al., (2007) and Stahl (2007) concluded that leadership is the key to success in determining the quality of GCG practices. The leader is responsible for the vision and quality of the company's GCG practices and all efforts to move the organization. Plowman et al., (2007) and Stahl (2007) assert that all organizations need leadership to guide organizations and that leaders are problem solvers who are able to guide companies to face challenges and get of achievements through the employees they lead. Stahl (2007) adds that corporate leadership has the capacity to direct staff in the right direction to realize the quality of GCG practices that are consistent with the company's philosophy and values. According to Rossouw (2009), trust in leaders is one of the factors that contribute to the rise of interest in corporate governance. There is hope that compliance with the principles and practices of good corporate governance will increase the trust of stakeholders in the business. Meanwhile, the dimensions of leadership according to Stahl (2007) include i) intellectual stimulation, ii) vision and 
philosophy and iii) directing ability. Comparison of Leadership Dimensions based on literature as in table 1. as follows:

TABLE 1: Comparison of Leadership Dimensions.

\begin{tabular}{|c|c|c|c|}
\hline No & Researcher & Year & Dimention \\
\hline 1 & Selznick & 1984 & - Vision and Quality of GCG Practices \\
\hline \multirow[t]{5}{*}{2} & Bass dan Avalio & 1995 & - Charisma \\
\hline & & & - Inspiration as role model \\
\hline & & & - Decision-making \\
\hline & & & - Intellectual stimulation \\
\hline & & & - Contingency award \\
\hline \multirow[t]{3}{*}{3} & Plowman et al., & 2007 & - Pattern of behavior \\
\hline & & & - Ability to manage words \\
\hline & & & $\begin{array}{l}\text { - The use of language that is easy to understand } \\
\text { (communicative) }\end{array}$ \\
\hline \multirow[t]{3}{*}{4} & Stahl & 2007 & - Vision and philosophy \\
\hline & & & - Directing ability \\
\hline & & & - Intellectual stimulation \\
\hline \multirow[t]{4}{*}{5} & Sotarduga & 2018 & - Vision \\
\hline & Napitupulu & & - Use of language that is easy to understand (communicatve) \\
\hline & & & - Behavior as a role model \\
\hline & & & - Intellectual stimulation \\
\hline
\end{tabular}

\subsection{Fit and proper test}

Another factor that is considered influence on the quality of GCG is the process of obtaining a bank leader or Fit and Proper Test. Initial research on this issue was carried out by Khalid and Nadeem (2004), who found that in both developed and developing countries, the quality of GCG practices was determined by the key criteria used in the Fit and Proper Test. This substance is supported by the results of research by Singh (2004), Dewing, and Russell (2004) who conducted research in the UK, Hussain (2005) in Malaysia, Jayasuria (2006) in Sri Lanka, Nam and Lum (2006) in several Asian and Sanusi countries (2010) in Nigeria. Similar research was also conducted on Islamic banks, such as by Wardhany and Arshad (2012) in Indonesia, Malaysia and Brunei. Broadly speaking, the results of Hopt's (2013) research published in the Journal of Corporate Law Studies (2013) concluded that previous researches proved the effect 
of Fit and Proper Test on the GCG quality implementation and that GCG practices in banks were very different than in other industries. One of the drivers of effective GCG implementation is the process that ensures that bank leaders lead and run the GCG process correctly is through a fit and proper test. Here are the opinions of experts regarding the definition of fit and proper test.

TABLE 2: Recapitulation Definitions of Fit and Proper Test.

\begin{tabular}{|c|c|c|c|}
\hline No & Researcher & Year & Definitions \\
\hline 1 & Barnard & 1986 & $\begin{array}{l}\mathrm{F} \& \mathrm{P} \text { is the feasibility test of the capability and quality needed } \\
\text { to guarantee the ability of candidates to carry out banking } \\
\text { management tasks in a proper and reasonable manner. }\end{array}$ \\
\hline 2 & $\begin{array}{l}\text { Khalid dan } \\
\text { Nadeem }\end{array}$ & 2004 & $\begin{array}{l}F \& P \text { is a process that connects the quality of candidate bank } \\
\text { managers with bank management requirements that are } \\
\text { appropriate and appropriate according to applicable } \\
\text { regulations }\end{array}$ \\
\hline 3 & Pawana & 2014 & $\begin{array}{l}\text { F \& P is an admissible and feasible test for Candidate's } \\
\text { Supreme Court Candidate by virtue of the authority granted by } \\
\text { Law No. } 3 \text { Year } 2009 \text { About the Supreme Court, especially in } \\
\text { Article } 8 \text { paragraph (2) }\end{array}$ \\
\hline 4 & $\begin{array}{l}\text { SE DK OJK NO. } 7 \\
\text { /SEDK.03/201 } 6\end{array}$ & 2016 & $\begin{array}{l}\text { The fit and proper assessment is a means for the OJK to } \\
\text { provide approval or rejection of the party that will own or } \\
\text { manage the bank }\end{array}$ \\
\hline 5 & Sotarduga & 2018 & $\begin{array}{l}\text { F \& P or PKK is the process of evaluating the integrity and } \\
\text { ability of prospective management and prospective bank } \\
\text { shareholders carried out by the Authority in accordance with } \\
\text { applicable regulations }\end{array}$ \\
\hline
\end{tabular}

Based on the exposure of the experts above, this study wants to synthesize that Fit and Proper Test is a process of evaluating the integrity and ability of prospective management and prospective bank shareholders carried out by the Authority in accordance with applicable regulations.

In this study, examining leadership variables and fit and proper variables as moderating variables on GCG practices in the banking industry in Indonesia. Based on the forming literature study determines the quality of GCG practices:

1. Leadership (Auh and Shih, 2007; Van, 2005; Nave, 2006; Plowman et al, 2007; Stahl, 2007)

2. Fit and Proper Test (Khalid and Nadeem,2004; Singh Dewing, 2004; Russell, 2004; Hussain, 2005; Jayasuria, 2006; Nam and Lum, 2006; Sanusi, 2010; Wardhany and Arshad, 2012 and Hopt, 2013).

Overall, clarify the following theoretical frameworks: 
TABLE 3: Comparison of Fit and Proper Test Dimensions.

\begin{tabular}{|c|c|c|c|c|}
\hline \multirow{2}{*}{$\begin{array}{l}\text { No } \\
1\end{array}$} & \multirow{2}{*}{$\begin{array}{l}\text { Researcher } \\
\text { Barnard }\end{array}$} & \multirow{2}{*}{$\begin{array}{l}\text { Year } \\
1986\end{array}$} & \multicolumn{2}{|c|}{ Dimention } \\
\hline & & & - Test material & -Banking regulations \\
\hline & & & - Test vision & $\begin{array}{l}\text { - Healthy banking } \\
\text { philosophy }\end{array}$ \\
\hline & & & - Response test & \\
\hline \multirow[t]{2}{*}{2} & Khalid dan Nadeem & 2004 & - GCG & - Banking philosophy \\
\hline & & & $\begin{array}{l}\text { - Effective and prudential } \\
\text { management }\end{array}$ & \\
\hline \multirow[t]{2}{*}{3} & Pawana & 2014 & $\begin{array}{l}\text { - Test of compliance } \\
\text { (integrity) }\end{array}$ & \\
\hline & & & $\begin{array}{l}\text { - Feasibility test } \\
\text { (competency) }\end{array}$ & \\
\hline \multirow[t]{3}{*}{4} & $\begin{array}{l}\text { SE DK OJK NO. } 7 \\
\text { /SEDK.03/ }\end{array}$ & 2016 & - Manage & \\
\hline & & & - ability & \\
\hline & & & - Obedience & \\
\hline \multirow[t]{2}{*}{5} & Sotarduga & 2018 & - integrity & \\
\hline & Napitupulu & & -Competence & \\
\hline
\end{tabular}

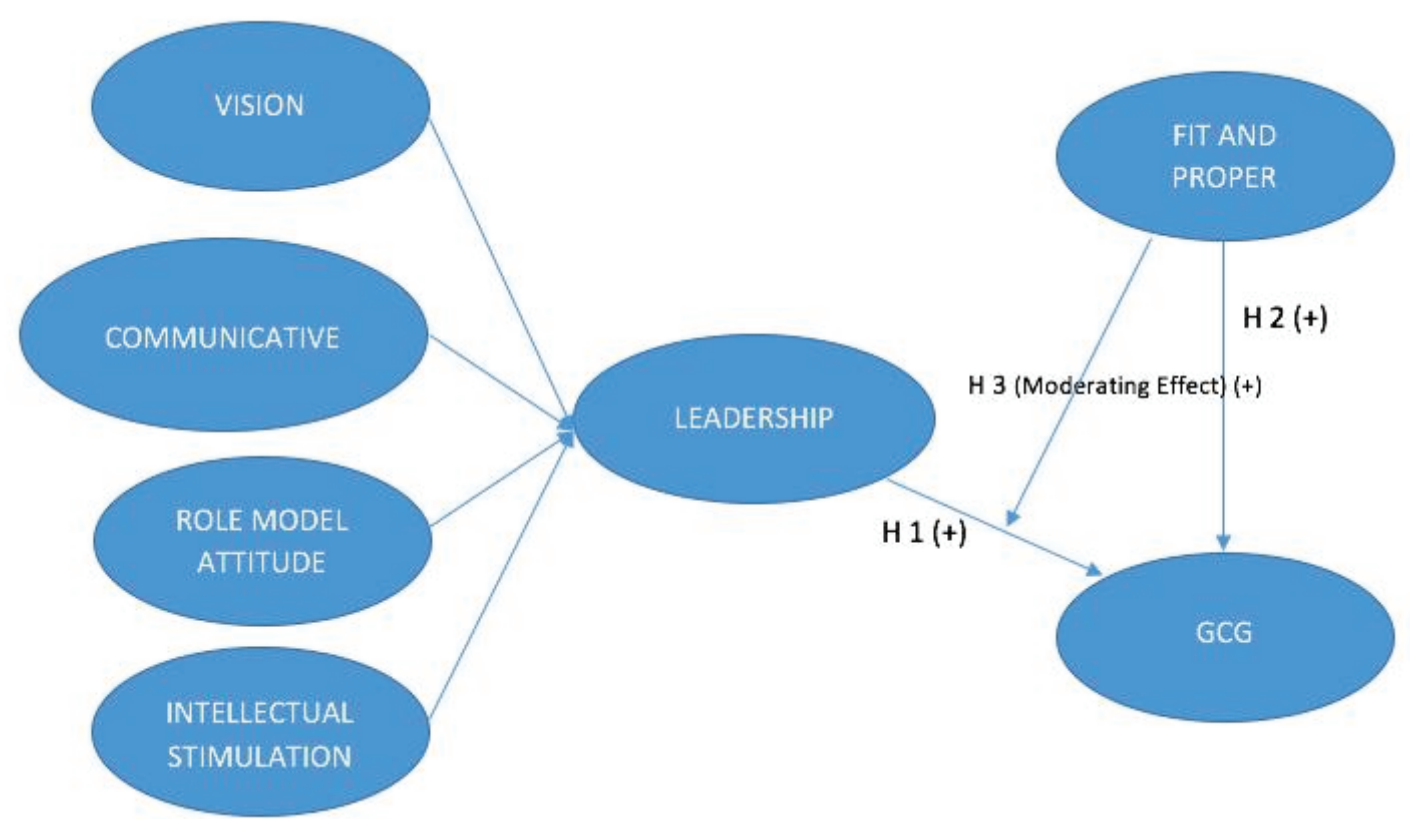

Figure 1: Theoretical Framework.

\section{Methodology}

The method used in this study is verificative research where research is carried out on the basis of a number of theories. From these theories developed hypotheses 
or temporary answers to research questions as outlined in the formulation of the problem. The step in testing these hypotheses is through an inferential approach to give conclusions at the end of the study. The analysis method starts from the presentation of descriptive statistics and continues with factor analysis and calculation based on Structural Equation Model (SEM).

H1: Leadership influences the quality of GCG practices of national commercial banks in Indonesia

$\mathrm{H} 2$ : Fit and proper test influences the quality of GCG practices of national commercial banks in Indonesia

H3: Fit and proper test is able to moderate the leadership variable that affect the quality of GCG practices of national commercial banks in Indonesia.

\section{Result and Discussion}

TABLE 4: Psychometric Properties for First Order Construct.

\begin{tabular}{|c|c|c|c|c|c|}
\hline Constructs & Items & Loadings & Alpha & $\mathrm{CR}$ & AVE \\
\hline \multirow[t]{3}{*}{ Vision } & $\begin{array}{l}\text { The Bank has established clear } \\
\text { responsibilities from each of the } \\
\text { ranks that are aligned with the } \\
\text { bank's vision, mission, business } \\
\text { objectives and strategies. }\end{array}$ & 0.952 & 0.943 & 0.959 & 0.855 \\
\hline & $\begin{array}{l}\text { The BoD has made GCG as part of } \\
\text { the company's vision and mission }\end{array}$ & 0.959 & & & \\
\hline & $\begin{array}{l}\text { The BoC has made GCG as part of } \\
\text { the company's vision and mission }\end{array}$ & 0.891 & & & \\
\hline \multirow[t]{3}{*}{$\begin{array}{l}\text { Communicative } \\
\text { (Language that is easy } \\
\text { to understand) }\end{array}$} & $\begin{array}{l}\text { Duties, responsibilities and } \\
\text { objectives of the Steering } \\
\text { Committee are defined and } \\
\text { evaluated regularly }\end{array}$ & 0.852 & 0.870 & 0.911 & 0.720 \\
\hline & $\begin{array}{l}\text { All banks operate the principles of } \\
\text { Good Corporate Governance (GCG) } \\
\text { in every business activity of the bank }\end{array}$ & 0.854 & & & \\
\hline & $\begin{array}{l}\text { The BoD provides the opportunity } \\
\text { for all stakeholders to provide inputs } \\
\text { and convey their views to the } \\
\text { interests of the bank and to have } \\
\text { access to information in accordance } \\
\text { with the principles of openness }\end{array}$ & 0.895 & & & \\
\hline \multirow[t]{3}{*}{ Role Model Behavior } & $\begin{array}{l}\text { BoD provides an example in } \\
\text { building quality work }\end{array}$ & 0.950 & 0.933 & 0.953 & 0.837 \\
\hline & $\begin{array}{l}\text { BoD delivers the Bank's advantages } \\
\text { and achievements in every forum }\end{array}$ & 0.951 & & & \\
\hline & $\begin{array}{l}\text { BoD conveys market potential that } \\
\text { can be worked on by the Bank in } \\
\text { each forum }\end{array}$ & 0.940 & & & \\
\hline
\end{tabular}




\begin{tabular}{|c|c|c|c|c|c|}
\hline Constructs & Items & Loadings & Alpha & CR & AVE \\
\hline \multirow[t]{3}{*}{ Intellectual stimulation } & $\begin{array}{l}\text { The Bank has a measure of } \\
\text { performance from all levels of the } \\
\text { bank based on agreed measures } \\
\text { consistent with corporate values, } \\
\text { business objectives and bank } \\
\text { strategies and has a reward and } \\
\text { punishment system. }\end{array}$ & 0.943 & 0.934 & 0.953 & 0.837 \\
\hline & $\begin{array}{l}\text { There are external professionals on } \\
\text { the Board of Directors / Advisory } \\
\text { Board }\end{array}$ & 0.896 & & & \\
\hline & $\begin{array}{l}\text { The company considers new } \\
\text { employees more in carrying out } \\
\text { their duties }\end{array}$ & 0.962 & & & \\
\hline \multirow[t]{3}{*}{ Fit and Proper } & $\begin{array}{l}\text { Reports are provided systematically } \\
\text { and regularly, for example: daily } \\
\text { reports, weekly reports, monthly } \\
\text { reports, semester reports, and } \\
\text { annual reports }\end{array}$ & 0.923 & 0.933 & 0.952 & 0.832 \\
\hline & $\begin{array}{l}\text { Every employee is able to work } \\
\text { according to the company's target }\end{array}$ & 0.917 & & & \\
\hline & $\begin{array}{l}\text { Every employee is willing to be } \\
\text { given an additional quantity of work } \\
\text { outside working hours if needed }\end{array}$ & 0.945 & & & \\
\hline \multirow[t]{5}{*}{ GCG } & Transparency & 0.946 & 0.945 & 0.964 & 0.901 \\
\hline & Akuntability & 0.946 & & & \\
\hline & Resposibility & 0.956 & & & \\
\hline & Independency & 0.932 & & & \\
\hline & Fairness & 0.864 & & & \\
\hline
\end{tabular}

TABLE 5: Mean, Standar Deviation, Intercorrelations of the latent variables for the first order construct.

\begin{tabular}{|c|c|c|c|c|c|c|c|c|}
\hline Construct & Mean & $S D$ & Visi & $\begin{array}{l}\text { Commu- } \\
\text { nicative }\end{array}$ & $\begin{array}{l}\text { Role } \\
\text { Model }\end{array}$ & $\begin{array}{l}\text { Intell- } \\
\text { ectual } \\
\text { Stimula- } \\
\text { tion }\end{array}$ & $\begin{array}{l}\text { Fit and } \\
\text { Proper }\end{array}$ & GCG \\
\hline Vision & 5.476 & 1.182 & $0.928^{*}$ & & & & & \\
\hline Communicative & 5.755 & 1.048 & 0.722 & $0.861^{*}$ & & & & \\
\hline Role Model & 5.082 & 1.321 & 0.688 & 0.689 & $0.923^{*}$ & & & \\
\hline Intellectual & 5.601 & 1.193 & 0.685 & 0.615 & 0.671 & $0.917^{*}$ & & \\
\hline \multicolumn{9}{|l|}{ Stimulation } \\
\hline Fit and proper & 5.382 & 1.271 & 0.775 & 0.688 & 0.672 & 0.683 & $0.913^{*}$ & \\
\hline GCG & 5.279 & 1.611 & 0.763 & 0.697 & 0.634 & 0.676 & 0.788 & $0.950^{*}$ \\
\hline
\end{tabular}

*square root of the AVE on the diagonal 
TABLE 6: Leadership (CR $=0.962$, AVE $=0.614$

\begin{tabular}{l|c|c|c|} 
Vision & Communicative & Role Model Behavior & Intellectual Stimulation \\
\hline $\mathrm{R} 2=0.801$ & $\mathrm{R} 2=0.727$ & $\mathrm{R} 2=0.775$ & $\mathrm{R} 2=0.730$ \\
\hline $\mathrm{B}=0.894$ & $\mathrm{~B}=0.861$ & $\mathrm{~B}=0.872$ & $\mathrm{~B}=0.864$ \\
\hline $\mathrm{P}<0.01$ & $\mathrm{P}<0.01$ & $\mathrm{P}<0.01$ & $\mathrm{P}<0.01$
\end{tabular}

In Figure 4A, the results give a standardized beta of 0.333 from fit and proper to the quality of GCG practices and 0.520 leadership to the quality of GCG practices. Thus, we find support for $\mathrm{H} 1$ and $\mathrm{H} 2$.

TABLE 7

Figure 4A: Main Effect Model

(A)

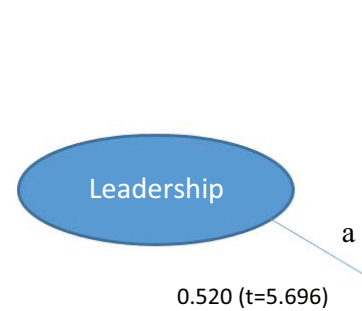

$0.520(t=5.696)$

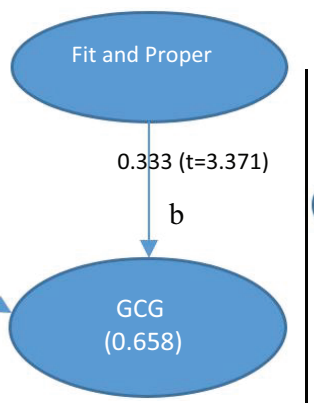

Figure 4B: Interaction Model

(B)

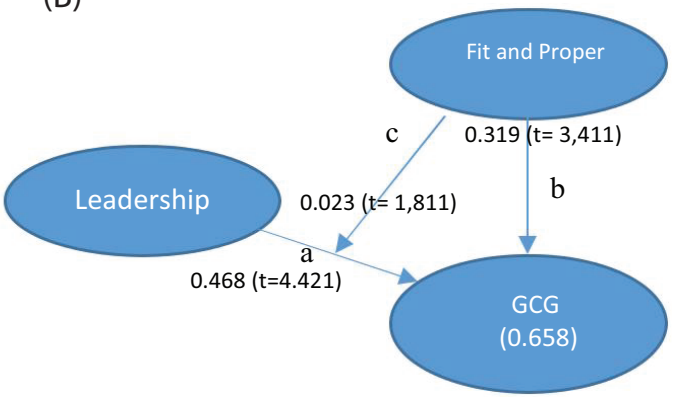

$\mathrm{H} 1^{*}$ : Leadership $\rightarrow$ GCG
H2*: Fit and Proper $\rightarrow$ GCG
H3*: Moderating effect (path c)

*significant at $p<0.01,{ }^{* *}$ significant at $p<0.05,{ }^{* * *}$ not significant

In Figure 4B, we present the moderation analysis applying PLS product-indicator approach (Chin et al. 2003) to detect the moderating effect of leadership on the relationship between fit and proper test and the quality of GCG practices. To test the possibility of such effect, leadership (predictor) and fit and proper test (moderator) were multiplied to create an interaction construct (fit and proper test $\times$ leadership) to predict the quality of GCG practices. In this case, leadership is a hierarchical construct which consists of 4 items and fit and proper test is a simple latent construct consists of 2 items, thus, the interaction construct represents 8 items $\left(4^{*} 2\right)$. The AVE and CR of this interaction variable are respectively 0.768 and 0.995 , which exceed the minimum cut off value.

To test the moderating effect, we have estimated the influence of predictor on criterion variable (b), the direct impact of the moderating variable on the criterion variable (c) and the influence of interaction variable on criterion variable (d) (see Fig. 
4B). The significance of a moderator can be confirmed if the interaction effect (path c) is meaningful, independently of the size of the path coefficients a and b (Hopt's, 2013). In this case, we have estimated a standardized path coefficient of 0.023 for the interaction construct (path $c$ ), which is significant at $p<0.05$ ( $t=1.811$ ). In estimating the significance of the interaction effect, we used two tailed test because there is a paucity of theoretical support whether leadership enhances or diminishes the association between fit and proper test and the quality of GCG practices. The effect size is calculated as follows:

$$
f^{2}=\frac{R_{i}^{2}-R_{m}^{2}}{1-R_{i}^{2}}=\frac{0.664-0.659}{1-0.664}=0.015
$$

Here, $i=$ interaction model, $m=$ main effect model

The results show that the size of the moderating effect is small $\left(f^{2}=0.02\right)$ as well as the resulting beta changes are insignificant $(\beta=0.023, t=1.811)$. Consequently, we confirm that fit and proper does moderate relationship between leadership and the quality of GCG practice, and we accept H3 (see Fig. 4B).

\section{Conclusion}

This study shows the leadership variables strengthen the quality of GCG practice. Fit and proper variable is proven to strengthen the influence of leadership variables on the quality of GCG practice. This research is useful for observers and researchers and can develop this research using different methodologies, variables, data, proxies because the topic of this research has not been conducted in Indonesia even though this topic is a problem in all countries in the world. This research is useful for mental banks, financial service authorities, banking practitioners to monitor GCG, especially the banking sector.

\section{References}

[1] Adams, R. B., \& Mehran, H. (2003). Is corporate governance different for bank holding companies?. Melalui https://papers.ssrn.com/sol3/papers.cfm?abstract_id=387561

[2] Alhazaimeh, A., Palaniappan, R., Almsafir, M. 2014. The impact of corporate governance and ownership structure on voluntary disclosure in annual reports among listed Jordanian companies. Procedia-Social and Behavioral Sciences. 127: 341-348.

[3] Anggiriawan, P.B., dan Wirakusuma, M.G. 2015. Pengaruh Gaya Kepemimpinan dan Budaya Organisasi terhadap Kinerja Organisasi dengan Penerapan Good 
Governance Sebagai Variabel Moderasi. E-Jurnal Akuntansi Universitas Udayana 10(2), 311-325

[4] Ansoff, H. I. (1972). The concept of strategic management. Journal of Business Policy, 2(4), 2-7.

[5] Aziz, N. A. A., Manab, N. A., \& Othman, S. N. 2015. Exploring the Perspectives of Corporate Governance and Theories on Sustainability Risk Management (SRM). Asian Economic and Financial Review, 5(10), 1148.

[6] Bank Indonesia. 2006. Peraturan Bank Indonesia Nomor 11/33/PBI/2009 tanggal 7 Desember 2009 - Pelaksanaan Good Corporate Governance Bagi Bank Umum Syariah dan Unit Usaha Syariah. Jakarta

[7] Bank Indonesia. 2012. Peraturan Bank Indonesia Nomor 14/26/PBI/2012 Tentang Kegiatan Usaha dan Jaringan Kantor Berdasarkan Modal Inti Bank. Jakarta.

[8] Barnard, D. M. 1987. The United Kingdom Financial Services Act, 1986: A New Regulatory Framework. In Int'l L. 21, 343.

[9] Barney, J. (1986). Organizational Culture: Can it be a Source of Sustained Competitive Advantage. Academy of Management Review, 11(3): 656-665.

[10] Barucci, E. (2005). Determinants of Corporate Governance in the Italian Financial Market. Journal of Economic Notes by Banca Monte dei Paschi di Siena SpA, vol. 34, no. 3-2005, pp. 371-405.

[11] Bass, B. M. 1985. Leadership and performance beyond expectations. Collier Macmillan.

[12] Bass, B. M., \& Avalio, B. J. (1995). Multifactor Leadership Questionnaire. Palo Alto: Consulting Psychologists Press.

[13] Bollard, A. (2003). Corporate governance in the financial sector. Melalui https://www. mysciencework.com/publication/show/2d995f7f32900d1283f4520b387ec81c

[14] Bushman, R. M., \& Smith, A. J. (2003). Transparency, financial accounting information, and corporate governance. Melalui https://papers.ssrn.com/sol3/papers. cfm?abstract_id=795547

[15] Camdessus (1997). The Asian Financial Crisis and the Opportunities of Globalization, Second Committee of the United Nations General Assembly New York. 11(5), 433450, Nov

[16] Cassel, C., Hackl, P., Westlund, A.H. 1999. Robustness of Partial Least Squares Method for estimating Latent Variable Quality Structures. Journal of Applied Statistics, 26 (4), 435-446.

[17] Davies, M.A. 2012. Best practice in corporate governance: Building reputation and sustainable success. England: Gower Publishing, Ltd. 
[18] Dewing, I. P., \& Russell, P. O. 2004. Accounting, auditing and corporate governance of

[19] Djokic, D., \& Duh, M. 2016. Corporate Governance Quality in Selected Transition Countries. Managing Global Transitions, 14(4), 335.

[20] Drobetz, W., Gugler,K., \& Hirschvogl, S. (2004). The Determinants of the German Corporate Governance Rating, WWZ Discussion Paper, No. 2004/06, University of Basel, Center of Business and Economics (WWZ), Basel.

[21] ElKelish, W. W., \& Hassan, M. K. 2015. Corporate governance disclosure and share price accuracy: Empirical evidence from the United Arab Emirates. Journal of Applied Accounting Research, 16(2), 265-286.

[22] Fauver, L., \& Fuerst, M. E. 2006. Does good corporate governance include employee representation? Evidence from German corporate boards. Journal of Financial Economics, 82(3), 673-710.

[23] Fauver, L., \& Fuerst, M. E. 2006. Does good corporate governance include employee representation? Evidence from German corporate boards. Journal of Financial

[24] Economics, 82(3), 673-710. Melalui http://www.sciencedirect.com/science/article/pii/ S0304405X06001140

[25] Gusnadi. 2008. Pengaruh peran Komite Audit dan Internal Control terhadap Pelaksanaan Good Corporate Governance (Studi pada BUMN terbuka di Indonesia). Sos/ohumanlora, 10(2), juli 2008: 58-72

[26] Hair JF, Sarstedt M, Pieper TM, Ringle CM. 2012. The Use of Partial Least Squares Structural Equation Modeling in Strategic Management Research: A Review of Past Practices and Recommendations for Future Applications. Long Range Planning, (45), 3.

[27] Hair, J.F., Ringle, C.M., Sarstedt, M. 2013. A Primer on Partial Least Squares Structural Equation Modeling. Sage, Thousand Oaks.

[28] Hair, Sarstedt, Pieper Torsten M.and Ringle Christian M. 2012. The Use of Partial Least Squares Structural Equation Modeling in Strategic management Research: A Review of Past Practices and Recommendation for Future Applications, Long Range Planning (45), 320-340.

[29] Henry, D. 2010. Agency costs, ownership structure and corporate governance compliance: A private contracting perspective. Pacific-Basin Finance Journal, 18(1), 24-46.

[30] Henseler J, Ringle CM, Sarstedt M. 2016.Testing Measurement Invariance of Composites Using Partial Least Squares. International Marketing Review, (33), Issue 3. 
[31] Holland, J. 1999. Financial reporting, private disclosure and the corporate governance role of financial institutions. Journal of Management and Governance, 3(2), 161-187.

[32] Hopt, K. J. 2013. Corporate governance of banks and other financial institutions after the financial crisis. Journal of Corporate Law Studies, 13(2), 219-253.Melalui http://www.tandfonline.com/doi/abs/10.5235/14735970.13.2.219

[33] Hussain, I. 2005). Corporate Governance in the Financial Sector. In Session Chairman's Address at the Seminar on Corporate governance organized by the Institute of Business Administration (IBA) at Karachi, Pakistan. Melalui http://ishrathusain.iba.edu.pk/speeches/financialSector/2005/ CORPORATE_GOVERNANCE_FINANCIAL_SECTOR.pdf

[34] Kanagaretnam, K., Lobo, G. J., \& Whalen, D. J. (2007). Does good corporate governance reduce information asymmetry around quarterly earnings announcements?. Journal of Accounting and Public Policy, 26(4), 497-522. Melalui http: //www.sciencedirect.com/science/article/pii/S0278425407000397

[35] Khalid, A. M., \& Hanif, M. N. 2005. Corporate governance for banks in Pakistan: Recent developments and regional comparisons.

[36] Khalid, A. M., \& Nadeem, H. 2004. Corporate Governance of Banks in Pakistan: A Profile. Centre for Management and Economic Research, Lahore University of Management Sciences, Lahore.

[37] La Porta, R., Lopez-de-Silanes, F., Shleifer, A., \& Vishny, R. (2000). Investor protection and corporate governance. Journal of financial economics, 58(1), 3-27. Melalui http: //www.sciencedirect.com/science/article/pii/S0304405X00000659

[38] Lattemann, C. 2014. On the convergence of corporate governance practices in emerging markets. International Journal of Emerging Markets, 9(2), 316-332.

[39] Leventis, S., \& Dimitropoulos, P. 2012. The role of corporate governance in earnings management: experience from US banks. Journal of Applied Accounting Research, 13(2), 161-177.

[40] Li, W., Xu, Y., Niu, J., \& Qiu, A. 2012. A Survey of Corporate Governance: International Trends and China's Mode. Bingley.

[41] Lipton, M., \& Lorsch, J. W. 1992. A modest proposal for improved corporate governance. The business lawyer, 59-77. Melalui http://www.jstor.org/stable/ 40687360?seq=1\#page_scan_tab_contents

[42] Macey, J. R., \& O’hara, M. (2003). The corporate governance of banks. https://papers. ssrn.com/sol3/papers.cfm?abstract_id=795548 
[43] Makki, M.A.M., Lodhi, S.A. 2014. Impact of Corporate Governance on Intellectual Capital Efficiency and Financial Performance. Pak J Commer Soc Sci, Pakistan Journal of Commerce and Social Sciences. Vol. 8 (2), 305- 330

[44] Menguc, B., Auh, S., \& Shih, E. (2007). Transformational leadership and market orientation: Implications for the implementation of competitive strategies and business unit performance. Journal of Business Research, 60(4), 314-321. Melalui http://www.sciencedirect.com/science/article/pii/S0148296307000136

[45] Mohr, J.J., Spekman, R.E. 1994. Characteristics of Partnership Success: Partnership Attributes, Communication Behavior, and Conflict Resolution, Strategic Management Journal, 15 (2), pp. 135-152, 1994.

[46] Mülbert, P. O. 2009. Corporate governance of banks. European Business Organization Law Review (EBOR), 10(3), 411-436.

[47] Nave, J. W. (2005). Leadership Styles of Entrepreneurs in Small Land Surveying Businesses. Melalui http://dc.etsu.edu/etd/1079/

[48] Nofianti, L., Suseno, N.S. 2014. Factors affecting implementation of good government governance (GGG) and their implications towards performance accountability. Procedia - Social and Behavioral Sciences 164 (2014) 98 - 105

[49] Ntim, C. G. 2016. Corporate governance, corporate health accounting, and firm value: The care of HIVIAIDS disclosures in Sub-Saharan Africa. The International Journal of Accounting. 51 (2): 155-216

[50] Othman, Z., dan Rahman, R. A. 2014. Attributes Of Ethical Leadership In Leading Good Governance. International Journal of Business and Society, 15 (2), 2014, 359 $-372$.

[51] Otoritas Jasa Keuangan. 2015. Salinan Surat Edaran Dewan Komisioner Otoritas Jasa Keuangan Nomor 8 /Sedk.02/2015 Tentang Akuntansi Aset Tetap Dan Aset Takberwujud. Jakarta.

[52] Otoritas Jasa Keuangan. 2016. Peraturan Otoritas Jasa Keuangan Nomor 55 /Pojk.03/2016 Tentang Penerapan Tata Kelola Bagi Bank Umum. Jakarta.

[53] Otoritas Jasa Keuangan. 2017. Surat Edaran Otoritas Jasa Keuangan Nomor 13/SEOJK.03/2017 Tentang Penerapan Tata Kelola Bagi Bank Umum.

[54] Pawana, I.K.B. 2014. Kewenangan DPR dalam Melaksanakan Uji Kepatutan dan Kelayakan Bagi Calon Pejabat Publik Dari Aspek Ketatanegaraan (Fit And Proper Test For Public The Officials Candidate Perspective On Constitutional Aspects), Jurnal IUS, II (5), Agustus 2014, 206-218

[55] Plowman, D. A., Solansky, S., Beck, T. E., Baker, L., Kulkarni, M., \& Travis, D. V. (2007). The role of leadership in emergent, self-organization. The Leadership 
Quarterly, 18(4), 341-356. Melalui http://www.sciencedirect.com/science/article/pii/ S1048984307000707

[56] Putri, I.A.D. 2012. Peranan Good Corporate Governance dan Budaya terhadap Kinerja Organisasi. AUDI Jurnal Akuntansi dan Bisnis, 7 (2), Juli 2012, 193-204

[57] Rafiee, V., dan Sarabdeen, J. 2012. The cultural influence in the practice of corporate governance in emerging markets. IBIMA Publishing, 2012(2012), 1-10.

[58] Robinson, R \& Pearce, J. 2015. Strategic Management. McGraw-Hill Education.

[59] Rose, P dan Hudgins, S. 2006. Bank Management and Financial Services.

[60] Segara, L.D. 2017. Analisis Determinan Good Government Governance serta Implikasinya pada Kualitas LAKIP. Jurnal Riset Akuntansi dan Keuangan, 5(1), 22 $-42$

[61] Selznick, P. 1984. Leadership in administration: A sociological interpretation. Univ of California Press.

[62] Shehata, N. F. 2015. Development of corporate governance codes in the GCC: an overview. Corporate Governance, 15(3), 315-338.

[63] Shleifer, A., \& Vishny, R. W. (1997). A survey of corporate governance. The journal of finance, 52(2), 737-783. Melalui http://onlinelibrary.wiley.com/doi/10.1111/j.1540-6261. 1997.tb04820.x/full

[64] Soleman, R. 2013. Pengaruh Pengendalian Internal dan Good Corporate Governance terhadap PT Cegahan Fraud. JAAI, 17 (1), Juni 2013: 57-74

[65] Soti, P., \& Gupta, S. K. 2013. Impact of corporate governance on the financial performance of Indian IT companies listed on stock exchanges. International Journal of Management Research and Reviews, 3(3), 2635.

[66] Sparkes, R. (2003). From Corporate Governance to Corporate Responsibility: The Changing Boardroom Agenda, Ivey Business Journal.

[67] Stahl, J. (2007). The influential leader. Leader to leader, 2007(46), 49-54. Melalui http://onlinelibrary.wiley.com/doi/10.1002//tl.257/full

[68] Stahl, J. 2007. The influential leader. Leader to leader, 2007(46), 49-54.

[69] Suhartati, T., Warsini, S., dan Sixpria, N. 2011. Pengaruh Pengungkapan Tanggung Jawab Sosial dan Praktik Tata Kelola Perusahaan Terhadap Nilai Perusahaan. Jurnal Ekonomi dan Bisnis, 10 (2), Desember 2011, 95-105.

[70] Sunardi. 2017. Etika Bisnis, Budaya Organisasi, Corporate Governance, Kinerja Perusahaan dan Komitmen Organisasi. Artikel, 20 Mei 2017: 131-139

[71] Teece, D.J., Pisano, G., Shuen, A. 1997. Strategic Management Journal, 18(7), 509533 
[72] Tisna, GA., dan Agustami, S. 2016. Pengaruh Good Corporate Governance dan Ukuran Perusahaan terhadap Kinerja Keuangan Perusahaan (Pada Perusahaan Perbankan yang Terdaftar di Bursa Efek Indonesia (BEI) Tahun 2010-2014). Jurnal Riset Akuntansi dan Keuangan, 4(2), 1035-1046

[73] Triyono dan Fatchan Achyani. 2016. Determinan dan Peran Kualitas Corporate Governance dalam Hubungan antara Struktur Kepemilikan dan Karakteristik Perusahaan dengan Kinerja Perusahaan. The $3^{\text {rd }}$ University Research Colloquium.

[74] Turrent, G. C. B., Ariza, L. R. 2016. Corporate governance ratings on listed companies: An institutional perspective in Latin America. European Journal of Management and Business Economics. 25 (2): 63-75

[75] Van, W. M. (2005). Dynamics of leadership in public service: Theory and practice. Armonk, NY: M. E. Sharpe. Melalui https://www.google.com/books?hl= $i d \& \mid r=\& i d=d V P f B Q A A Q B A J \& o i=f n d \& p g=P P 1 \& d q=V a n,+W .+M .+(2005) .++$ Dynamics + of+leadership+in+public+service:+Theory+and+practice\&ots=BcLFQZs4tO\&sig= v91Mc1mmcZtmxdDq6g4DOiGzVjs

[76] Wahab, E. A. A., Zain, M. M. \& James, K. 2011. Political connections, corporate governance and audit fees in Malaysia, Managerial Auditing Journal, 26(5), 393418.

[77] Wang, C. H., \& Hsu, L., C. 2010. The influence of dynamic capability on performance the high technology industry: the moderating roles of governance and competitive posture. African Journal of Business Management, 4(5): 562-577

[78] Wati, L.M. 2012. Pengaruh Praktek Good Corporate Governance terhadap Kinerja Keuangan Perusahaan di Bursa Efek Indonesia. Jurnal Manajemen, 01 (01), September 2012, 1-7

[79] Wheelen, T. L., \& Hunger, J. D. 2012. with contributions by Wheelen KE and Hoffman. AN, "Strategic Management and Business Policy: Toward Global Sustainability 13th Edition," New Jersey, US: Pearson Education.

[80] Wheelen, T. L., Hunger, J. D., Hoffman, A. N., \& Bamford, C. E. (2015). Concepts in Strategic Management and Business Policy: Globalization, Innovation, and Sustainability.

[81] Widjaja, F., dan Mustamu, R.H. 2014. Pengaruh Sistem Pengendalian Internal terhadap Implementasi Prinsip-prinsip Good Corporate Governance pada Perusahaan Industri keramik. AGORA, 2(1)

[82] Widjajanti, K., dan Sugiyanto, E.K. 2015. Gaya Kepemimpinan dan Good Governance Sebagai Upaya Peningkatan Excellent Service Dan Kepercayaan Masyarakat (Studi 
Kasus Dinperindag Jawa Tengah). J. DINAMIKA SOSBUD, 17 (2), Desember 2015: $270-284$

[83] Widuri, R., dan Paramita, A. 2007. Analisis Hubungan Peranan Budaya Perusahaan Terhadap Penerapan Good Corporate Governance pada PT Aneka Tambang Tbk. Journal The WINNERS, 8(2), September 2007: 126-138

[84] Wu, X. Z. 2012. Corporate governance and audit fee: Evidence from companies listed on the Shanghai Stock Exchange. China Journal of Accounting Research. 5 (4): 321-342

[85] Young, S., \& Thyil, V. 2014. Corporate social responsibility and corporate governance: Role of context in international settings. Journal of Business Ethics, 122(1), 1-24. 